\title{
Evaluation of Techno-Initiative Capital Support Program in Building Entrepreneurial Ecosystem within the Scope of Social Marketing
}

\author{
Selma Kalyoncuoglu ${ }^{1} \&$ Emel Faiz $^{2}$ \\ ${ }^{1}$ Department of Business Administration, Faculty of Economics and Administrative Sciences, Gazi University, \\ Ankara, Turkey \\ ${ }^{2}$ Department of International Trade, Faculty of Business Administration, Duzce University, Duzce, Turkey \\ Correspondence: Selma Kalyoncuoglu, Department of Business Administration, Faculty of Economics and \\ Administrative Sciences, Gazi University, Muammer Bostanci Cad., Besevler, Ankara, Turkey.
}

Received: August 7, 2017

doi:10.5539/ibr.v10n10p132

Accepted: September 18, 2017

Online Published: September 22, 2017

URL: https://doi.org/10.5539/ibr.v10n10p132

\begin{abstract}
The aim of this study it to investigate and find out the contributions of Techno-Initiative Capital Support (TICS) grant which was provided by the Ministry of Science, Industry and Technology for early-stage entrepreneurs to building entrepreneurial ecosystem in Turkey. Within this framework, voluntary behaviour change which the Ministry of Science, Industry and Technology tried to create in young entrepreneurs who received the grant was tackled through social marketing approach. TICS grant program was planned as a way of solution by the Ministry as the public authority in order to provide benefit to the society without expecting any material profit in return. Therefore, the grant program of the Ministry was e valuated within the scope of social marketing by the researchers since the program encouraged and mobilized early-stage young entrepreneurs to develop technology-based business ideas so that entrepreneurial ecosystem could be built in the country. In this study, purposive sampling technique was used and interviews were carried out with four entrepreneurs who received grant from the Ministry's TICS program before and started their own companies in Gazi University Technopark. Qualitative research method was applied in the study, interviews were recorded and collected data were analysed by using a qualitative data analysis program, NVivo10. Entrepreneurs who received the grant stated that grants given to them within the scope of TICS program for their technology-based business ideas contributed to building entrepreneurial ecosystem in Turkey. Within this scope, it is seen that contributions were clustered under three themes as development of societal welfare, emergence of entrepreneurship awareness and power formation to create innovation. Furthermore, all the young entrepreneurs who obtained the grant stated that TICS caused change in their behaviours, thus they and the target audience of the program "developed technology-based business ideas" as an expected result of the program. Findings of the study confirm that in order to have an innovation-based economy, TICS reacted to the building an entrepreneurial ecosystem which is necessary for the benefit of the society with the driving force of the social marketing.
\end{abstract}

Keywords: entrepreneurial ecosystem, Techno-Initiative Capital Support (TICS) Grant Program, social marketing, qualitative research.

\section{Introduction}

Republic of Turkey needs to show a progress from developing countries league into developed countries league in order to reach export target of 500 billion dollars in 2030. For this, Turkey needs to become a country which "produces and sells its own technology" rather than a country which buy technology. For this reason, public authority in Turkey started to implement Techno-Initiative Capital Support (TICS) program under the auspices of the Ministry of Science, Industry and Technology for building entrepreneurial ecosystem within the country. This program started in 2009 in a way which allows young people at the early-stage who have entrepreneurship potential and tendency to commercialize their ideas and transform them into companies producing technology-based goods and services. This program was initiated to contribute to R\&D and innovation-based policies in the country by providing grants to early-stage entrepreneurs.

In the Schumpeter's Theory of Economic Development, "entrepreneur" plays a significant role as driving force of economic development in the realization of innovations. Especially in a developing country like Turkey, "entrepreneurship" is as an important parameter as labour and capital in enabling and sustaining economic 
development. Accordingly, young population which represents Y generation who are open and prone to technology and innovation are considered to be those entrepreneurs who will realize innovation in Turkey. Therefore, it is aimed to maintain economic development in the country by making best use of leverage effect of young entrepreneurs. There are a high number of studies in the literature which show that entrepreneurship has a significant function in mobilizing economic growth and de velopment in countries (Castano, Mendez, \& Galindo, 2016; Galindo \& Mendez-Picazo, 2013; Kritikos, 2015; Wennekers \& Thurik, 1999). Hence, it is envisaged that innovations introduced by entrepreneurs will contribute to the production of products with high added value at micro level and to building entrepreneurial ecosystem in the country at macro level. Considering this fact, Republic of Turkey endeavours to create an environment in which entrepreneurs produce knowledge and transform this knowledge into technology-based goods and services, thus making sure that wheels of economy are turning even stronger. In this way, economic growth will ensure the development of societal life both in material and moral way. Especially with export-oriented strategy, a paradigm shift has been created and TICS program as one of the activities that will help Turkey to reach high competition power at global scale was launched to serve for this purpose.

Ministry of Science, Industry and Technology who is responsible for the implementation of TICS grant program has made use of social marketing in order to act for the good of the society in the establishment of economic growth as a part of development and to ensure behavioural change in the target audience. Social marketing is defined as applying marketing principles and techniques for influencing target audience to make sure that a behaviour is voluntarily accepted, refused, changed or abandoned for the sake of individuals, groups or society as a whole (Kotler, Roberto, \& Lee, 2002, p. 5). Social marketing principles and techniques can be applied by three different types of practitioners as "public institutions and organizations", "non-profit organizations, associations" and "profit-oriented organizations" (Kotler, Roberto, \& Lee, 2002, p. 12-13) to contribute to the realization of various aims. As it is well known, marketing achieves the change between buyer and seller. With TICS grant program, the Ministry has used social marketing to create a change for the benefit of the society. "Ministry as public institution providing the grant" who is in the position of seller has realized social marketing program as an institutional contribution to the society in the realization of the desired behaviour in "potential young entrepreneurs who receive the grant as buyers." Within this regard, the Ministry as the public authority has moved forward taking into account that young entrepreneurs chosen as target audience need to be supported. Similarly, technology-based enterprises which will produce innovation need to be established in order to develop entrepreneurial ecosystem and innovation climate in the country. It is clear that there is a need for young entrepreneurs who closely follow technology and are prone to technology and who will establish abovementioned enterprises and transform their technology-based business ideas into goods and services which have the potential to be commercialized. Within this framework, the Ministry has introduced TICS grant amounting to $100.000 \mathrm{TL}$ in the related period as a social product for the society so that the society can make best use of the economic growth of Turkey. This product is an important tool which has been used to encourage target audience and to make sure that a behaviour which will benefit the society is adopted, thus providing an opportunity for target audience to develop technology-based business ideas.

It is envisaged that individuals who have been granted to take advantage of TICS program will become entrepreneurs by establishing their technology-based enterprises, will be situated within qualified young employment, and will contribute greatly to building entrepreneurial ecosystem and climate in the country by producing products which have high added value. To reach this goal, enterprises which produce and sell their own technology have always worked towards achieving the vision of having high competition power in a global scale by developing innovation ecosystem and climate and by steering the direction of the country towards export. In this way, it has been aimed and is still aimed to ensure that society develop and prosper thanks to economic development of the country.

It is seen that studies on social marketing are generally about developing health, preventing injuries, protecting the environment and realizing society's participation in activities (Lefebvre, 2011, p. 56-57; Kotler, Roberto, \& Lee, 2002, p. 15-16; Stead, Hastings, \& McDermott, 2007, p. 189). The topic of the study which is the value that will be provided for the society by the entrepreneurial ecosystem which will be built by young entrepreneurs supported by public authority has never been studied before in both national and international literature. The approach of social marketing has been lacking in Turkey in the creation of entrepreneurial ecosystem as a system which feeds, protects and improves entrepreneurs while providing societal benefit (Marangoz, 2016, p. 9). Based on this fact, this study aims at revealing the contributions of TICS grant to building entrepreneurial ecosystem by making best use of knowledge, opinions and experiences of early-stage entrepreneurs who benefit from this grant. In this process, the impact and contributions of TICS as a kind of seed funding in creation of 
entrepreneurial ecosystem in the country when used properly was tackled with social marketing approach.

\section{Theoretical Framework}

\subsection{Techno-Initiative Capital Support (TICS) Program of Ministry of Science, Industry and Technology}

TICS program of the Ministry was planned as a support and promotion mechanism which is granted to early-stage entrepreneurs so that innovative business ideas and the market can meet, and the program entered into force with "Law on Supporting Research and Development Activities" numbered 5746. The grant program which was regularly given to young entrepreneurs for support by the Ministry between 2009 and 2015, was terminated in 2015 following two calls for application. The grant program was introduced as a me ans to provide an environment for the realization of technology-based and innovation-oriented business ideas by increasing qualified workforce employment. In this context, the whole of the grant amounting 100.000 TL was given to young entrepreneurs just once only without any deposits within a year as a $100 \%$ grant. Students who will graduate from any department of a university within a year, currently master's and $\mathrm{PhD}$ students or individuals who have obtained bachelor's, master's or $\mathrm{PhD}$ degree within the last five years were eligible to apply for the grant

(http://www.resmigazete.gov.tr/main.aspx?home=http://www.resmigazete.gov.tr/eskiler/2008/03/20080312.htm

\&main=http://www.resmigazete.gov.tr/eskiler/2008/03/20080312.htm). An assessment commission including a representative from the Ministry and academicians reviewed applicants' business plans about their business ideas and listened to young entrepreneurs' presentations, then asked those who were approved for receiving the grant to set up their businesses and present at least one prototype of their technology-based products/processes at the end of the related term. With this monitoring and assessment process, whether entrepreneurs carried out their business ideas based on their business plans was controlled (https://biltek.sanayi.gov.tr/TSD\%20Dkmanlar/Uygulama\%20Usul\%20ve\%20Esaslar1.pdf). Another financial support granted to young early-stage entrepreneurs in Turkey was provided by TUBITAK (The Scientific and Technological Research Council of Turkey) via "1512 Techno-Initiative Capital Support Program", this program was very similar to the Ministry's TICS program in terms of its aim and objectives. It was another available grant for entrepreneurs between 2012 and 2015. TUBITAK's program was revised radically in 2015 and started to be implemented as "1512 Techno-Initiative Capital Support Program BIGG". However, with a recent change in 2017, these two grant programs were integrated and turned into one single program in order to overcome mistakes and deficiencies experienced in both programs during their applications. Grant program which was carried out by the Ministry between 2009 and 2015 was merged into TUBITAK 1512 program which was still effective, and updated content was introduced as "1512 Techno-Initiative Capital Support Program BIGG" in 2017.

\subsection{Concept of Social Marketing and Its Development}

Origins of the understanding of social marketing dates back to studies of researchers such as Wiebe, Meendelsohn, Lazrsfeld, Merton, Hyman and Sheatsley in 1940s and 1950s (Rothschild, 1997, p. 308). The first conceptual study on social marketing approach which marketing researchers have focused on as of 1960s was conducted by Kotler and Zaltman (1971), they carried out a study which showed how social problems could be solved more successfully and how social problems could be controlled efficiently by using marketing principles. Researchers think that social problems can benefit from the idea and application of marketing (Kotler \& Zaltman, 1971, p. 11) and argue that social marketing is far beyond just being a social communication and even social advertising approach. Social marketing was defined by the authors as "Social marketing is the design, implementation, and control of programs calculated to influence the acceptability of social ideas and involving considerations of product planning, pricing, communication, distribution, and marketing research" (Kotler \& Zaltman, 1971, p. 5). On the other hand, Andreasen (1994) argued that this definition had some problems and proposed the following definition "Social marketing is the adaptation of commercial marketing technologies to programs designed to influence the voluntary behaviour of target audiences to improve their personal welfare and that of the society of which they are a part." (Andreasen, 1994, p. 110).

Social market does not just mean selling an idea or a product which is defined as good or suitable for a specific group of people. On the contrary, social marketing aims at determining the scale of problems together with the members of the society, finding priorities and possible solutions for the problems, and with the same members of the society conveying these possible solutions to other members of the society (Bekar, 1995, p. 83). What's important is that social marketing approach also applies to leading to behaviour changes in key players whose cooperative actions are needed to make programs successful. These key players may include the media, policymakers, legislators, and managers (Andreasen, 2002, p. 8). 
Focus point in social marketing is the behaviour. Social marketing approach whose main purpose is to influence the behaviour, states that marketing can yield strong technological infrastructure potentially in developing socially-desired behaviours. This new understanding forms the driving force of social marketing movement (Goldberg et al., 1997, p. 3 cited by Kurtoglu, 2007, p. 129). It is possible that the behaviour change occurs once or it can be continuous. However, for people in the field of social marketing, it becomes easier to target a behaviour change occurring once than to target behaviour change which requires continuity (Bayraktaroglu \& Ilter, 2007, p. 127).

There are similarities and differences between social marketing and commercial marketing. One of the most significant similarity stems from the fact that social marketing makes use of principles and policies of commercial marketing. The difference between the two is that social marketing deals with more fundamental issues rather that superficial market problems. Benefits resulting from social marketing spread towards not only companies but also society as a whole including all individuals and all companies (Ilter \& Bayraktaroglu, 2007, p. 51). While product and money are exchanged in commercial marketing; psychological, social and intangible factors are the means of exchange in social marketing (Bayin \& Akbulut, 2012, p. 64). It is of significant importance that social marketing is more difficult than commercial marketing. Marketing process is used to sell a desired behaviour in social marketing (Kotler \& Lee, 2010, p. 99). It is more difficult to make people adopt or change their behaviours such as quitting smoking, eating healthy, fight against alcohol and drug addiction through social marketing rather than to present, position and sell a product or service in the market (Eser \& Ozdogan, 2006, p. 9). At that point the importance of social marketing emerges. A company which adopts social marketing approach not only meet the wishes and needs of their customers but also fulfil their responsibility towards the society which stems from their actions and activities.

There are some concepts which are associated with social marketing in the related literature and which even cause conceptual confusion and misuse and replacement. Concepts of societal marketing and corporate social responsibility can be given as examples. Societal marketing is business driven, profit orientated way of changing the world. While in societal marketing, while the primary aim is the profitability of the company, the benefit of the society remains at the secondary level. In addition, in societal marketing, the benefit of the society is calculated together with the profitability of the company. However, in social marketing the profits of company or individuals are not even considered for calculation (Ayvaz \& Torlak, 2016, p. 252). What is aimed at social marketing is to provide benefit of the broader society by creating behaviour change (McColl-Kennedy et al., 1994 cited in http://stephendann.com/2009/07/21/societal-marketing-v-social-marketing/).

According to Kotler and Lee (2008, p. 11), corporate social responsibility is a liability which is assumed to enhance the society's welfare through business applications and contributions of corporate resources (Bali \& Cinel, 2011, p. 47). Corporate social responsibility is about the general management understanding of the company and it integrates into company's strategies, culture, values and its activities. While social marketing is generally considered to be the state's responsibility, corporate social responsibility has become an important issue for profit-oriented companies (Kestane, 2014, p. 197). Companies which show corporate social responsibility can raise awareness in the society by doing so, can enter into new markets and have new clients. In other words, as a whole interests and contributions shown to societal events serve for commercial purposes. However, in social marketing, primary aim is to be useful to the society by creating change in behaviour.

When we look at the areas in which social marketing is commonly applied and utilized, issues such as pollution and its control, drug, smoking and alcohol addiction problems, in general public health and use of medications come to the foreground. In the field of health, there have been intensive studies on social marketing. In a study by Van Duyn et al. (2007), it was found that there was an effect of social marketing in utilization of evidence-based strategies to increase physical activities of ethnic groups. In this study in which focus groups were used as a method, it was observed that all ethnic groups showed positive feedback thanks to the social support they received. When we look at how social marketing is applied in environmental issues, in the study of Uslu and Marangoz (2008) which was carried on environment volunteers' organization, it was found that organizations struggle determining target audience and developing social marketing mix which is appropriate for the target audience. When the issue of consumerism of the $21^{\text {st }}$ century is considered, it is clear that a study which dwells on how consumption can be decreased with social marketing will be of great use for the society. Similarly, Peattie and Peattie (2009) have shown a view of demarketing and have drawn attention to how difficult it would be to have the concept of demarketing in highly consumption-oriented societies. Saran and Bitirim (2010) who showed a different point of view regarding the use of social marketing in the fight against terrorism which is a common threat for all societies apart from its use in areas such as health, environment, welfare etc., argued that factors such as ethnic differences, the mosaic of the society and culture of cohabiting 
need to be considered while preparing a social marketing program. Rad and Karatas (2013) who carried out a study on a social marketing application for the fight against poverty which is one of the important problems in the world, stated that rural development programs in our country are not sufficient and they do not reach the necessary target. In their study, Bozpolat and Comert (2016) who aimed at measuring the tendency of people living in Nevşehir towards social marketing applications for struggle against obesity which is one of the most important issues of the last century, observed that there are differences between the genders in terms of their attitudes towards the campaign for fight against obesity, promotional method and efficiency of the campaign. As expected, it was found that women showed more interest a social marketing application such as the campaign for fight against obesity. Ekiyor and Cetin (2017) conducted a social marketing study in another area of health on the familiarity of e-pulse application. It was found that familiarity of the application was at medium level and this showed the need for social marketing programs in this area. As can be seen in the aforementioned studies, it can be said that the phenomenon of social marketing aims at increasing the welfare standards of the society beyond gaining commercial profit (Argan \& Akyildiz, 2010, p. 41).

\subsection{Use of Social Marketing in Building Entrepreneurial Ecosystem}

Solutions offered for social issues in the public sector have huge opportunities compared to other sectors. The reason for this is that the state has the potential to use all resources and opportunities of the society till the end in the name of innovation or refreshment (Sarikaya et al., 2010, p. 209). When considered in this way, the success chances of the state's approach to social issues, the solutions it offers and its applications are higher. Some of the issues that the states are concerned with are the welfare of the society, their life quality and overcoming the problem of unemployment by employing individuals. The state is not just responsible to offer job opportunities in just public sector, it presents opportunities to individuals to improve themselves and to start their own enterprises by providing capital support for entrepreneurial thinking. Therefore, it is crucial to spread the culture of entrepreneurship throughout the country, to promote the spirit of entrepreneurship and to build an entrepreneurial ecosystem in the country.

When we looked at from the perspective of individuals, Erkut (2013) states that the most chaotic and risky period of an initiative is the breaking point and early-stage period following the breaking point. He points out that in this period it is not possible for an entrepreneur to access to venture capital therefore they mostly refer to their close circle which is also defined as "family, friends and founders". He emphasizes that states that beginning period in which entrepreneurs cannot get serious support from others is the most effective period for states which wish to develop entrepreneurship in their countries to play an active role. He underlines that "Techno-Initiative Capital Support" (TICS) program which was implemented by the Ministry of Science, Industry and Technology since 2009 serves exactly for this purpose (http://erhanerkut.com/girisimcilik/teknogirisim-sermayesi-destegi-mi-engeli-mi/)". The grant program of the Ministry which was thought to affect both entrepreneurs at individual level and also the society which the entrepreneur is a part of, was realized in order to have an impact on the behaviours of target audience. In this scope, TICS program as a social marketing application which plays an important role in paving the way for building "entrepreneurial ecosystem and innovation climate in the country" and for transforming the inactivity structure of the tendency and interest of target audience towards technology into an action was investigated with a qualitative research method. In this way, behaviour which is expected to be adopted by the society will ensure that the society's life is improved and a behaviour that will benefit the whole society is developed and sustained.

Within the scope of social marketing application, the research question of the study was defined as follows:

Research Question: Does the Techno-Initiative Capital Support grant program which was implemented by the Ministry of Science, Industry and Technology of Republic of Turkey as a social marketing application contribute to building an entrepreneurial ecosystem in the country?

\section{Method}

\subsection{Population and Sample of the Study}

Since there was not any previous study on the topic of the research in the literature, this study was planned as exploratory research (Gegez, 2007, p. 37-38). Young entrepreneurs who applied for "Techno-Initiative Capital Support" grant program of the Ministry of Science, Industry and Technology which aimed at encouraging qualified entrepreneurship in our country, and who turned the support into an enterprise comprised the population of the study. Research field was limited because of reasons such as time and cost. Considering the aim of the study, purposive sampling technique was thought to be appropriate to use as it is commonly applied in qualitative research (Saillard Kus, 2010, p. 15). Purposive sampling is based on the assumption that it is compulsory to choose a sample when the researcher wants to explore, understand, gain an insight and thus learn most of the things 
from the sample (Merriam, 2013, p. 76). Therefore, while choosing the working group which will constitute the sample for the study, specific criteria were applied; early-stage entrepreneurs who received the grant between 2009 and 2014 (first criterion), who started a company in Gazi Technopark with their grant (second criterion) and who wish to participate in the study voluntarily (third criterion). A total of five entrepreneurs who met all the selection criteria were determined as a result of talks and reviews with the management of Gazi Technopark.

\subsection{Data Sources}

Primary data sources which were considered to be appropriate for the scope and aim of the study were used in this research. Data were collected through face-to-face depth interview technique which was utilized during the interviews with entrepreneurs who have received Techno-Initiative Capital Support which is granted by the Ministry of Science, Industry and Technology and who successfully continue their initiatives in Gazi University Technopark between September 2015 and March 2016.

\subsection{Research Method and Technique}

Taking into account the research problem of the study and previous studies in the related literature, qualitative research method was applied to carry out this research. One of the qualitative research methods, depth interview technique was preferred in this study since the research problem was not tackled studied before at least according to the best knowledge of the researchers and comprehensive information would be gathered if each and every member of the sample were reached individually. Depth interview technique is one of the significant qualitative data collection tools which enables gathering depth information on the topic and which is commonly used in qualitative research (Mil, 2007, p. 3). Generally, interview technique can be designed in three ways (Punch, 2011, p. 161). In this study, semi-structured interview technique was adopted because of the nature of the study and an interview form including questions to be asked was prepared by the researchers in advance. The advantages of semi-structured interview technique were utilized and during the interviews the order of the questions was changed when deemed necessary and probing questions such as "Can you dwell upon it a little more?" were asked so that interviews were detailed further (Mil, 2007, p. 3).

The interview form is composed of three parts. The first part included questions for gathering information about entrepreneur candidates who were granted to receive Techno-Initiative Capital Support; the second part included questions about the support given by the Ministry and the last part included open-ended questions about whether the support given by the Ministry could be evaluated within the framework of social marketing concept. While preparing these questions, related literature and previous experiences of researchers on this topic were made use of.

After interview form was prepared, necessary steps were taken to reach related parties in Gazi Technopark and appointments with related people were arranged. Howe ver, interview with one of the entrepreneurs who was in sample of the study could not be conducted, thus depth interviews were carried out by the researchers with a total of four entrepreneurs at the end. Interviews with four early-stage entrepreneurs were found to be sufficient since the ideal number for case studies is between four and twelve (Yin, 1994). Duration of interviews was at least one and a half hours and at most two hours.

\subsection{Credibility and Transferability}

Lincoln and Guba (1985) propose some strategies to increase the quality of qualitative research. While concepts of "validity" and "reliability" are used traditionally in quantitative research, in qualitative research "credibility" is used instead of "internal validity", "transferability" is used instead of "external validity"; "dependability" is used instead of "internal reliability" and "conformability" is used instead of "external reliability" (Yildirim \& Simsek, 2011, p. 264).

Within this scope, long duration interaction was achieved in order to have credibility. Since one of the researchers was also involved in assessment commission of the Ministry's Techno-Initiative Capital Support (TICS) Grant program, she had the opportunity to observe the grant program closely, and had a chance to make detailed review about the topic with experts in the Ministry and experts working in Technopark. In this way, interaction between researchers and data source extended over a long time. More than one data collection methods were used by bringing together data collected after these activities, and interview data and field notes. It is a natural expected result to have differences in data sources of the study. Data triangulation was utilized in order to transform differences into wealth. Triangulation is analysed under various titles such as triangulation of data sources, method and researcher (Yildirim \& Simsek, 2011, p. 267). Within this study, both data source triangulation and researcher triangulation were applied. In addition to data triangulation explained above, researcher triangulation was realized as follows: two researchers participated in data collection and analysis 
phases of the study; they analyzed the same qualitative data separately and compared their findings independently (Merriam, 2013, p. 206). In this way, credibility of the study was assured.

While transferability means to what extend the results of the study can be applied in different situations, it also shows that the results can be generalizable in similar situations and conditions. Actually, generalization is not the aim of a qualitative research, a qualitative research serves for exploring and understanding a problem. Therefore, in case studies generalization is analytic and means the generalization of detailed results while developing a comprehensive theory (Yin, 1994, p. 36). Erlandson, Harris, Skipper and Allen (1993) suggest detailed description and purposive sampling in order to increase the transferability of research results. Therefore, findings of the study were shared as direct quotations in order to ensure transferability. Furthermore, purposive sampling was used as explained in data and method part.

\subsection{Data Analysis}

Voice recordings collected during depth-interview were transcribed one-by-one by the researchers. Researchers carried out data analysis systematically. In general, the model of Miles and Huberman (1994) was adopted in data analysis. Miles and Huberman (1994) define data analysis process in qualitative researches as interactive simultaneous flows or activities. Therefore, they propose an interactive model.

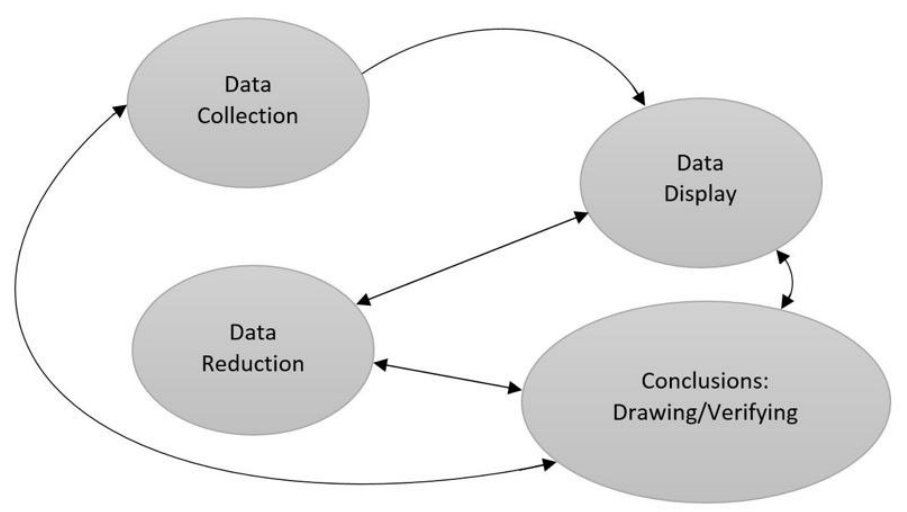

Figure 1. Components of Data Analysis: Interactive Model

(Source: Miles \& Huberman, 1994, p. 12 cited by Punch, 2011, p. 192.)

Data were subjected to early data analysis after each interview. During the analysis of data, field notes were utilized. Field notes are narratives composed of researchers' descriptions based on their experiences and observations during the interviews in which they get involved in intensely (Emerson, Fretz \& Shaw, 2008, p. 6). Field notes taken during interviews and observations were valuable resources in reaching conclusions.

Interviews and field notes were uploaded to NVivo10 which is a qualitative data analysis program. Analyses were performed via this package program. Coding process based the data are entitled as "in-vivo" coding (Glaser \& Strauss, 1967 cited by Saillard Kus, 2010, p. 17). In the first step, data were coded, categorized and gathered under themes. Data were scrutinized line by line then categorized; any word or concept within the data set could be a category name. In the second step, data were organized and summarized and in the final step themes were formed and associated through comparison.

\section{Findings}

\subsection{Findings Regarding Demographic Characteristics of Participants}

In the research, some demographic information about participants was obtained. Since such information would be useful for the topic of the research and other findings gathered in the study, demographic information on sample was summarized in the following table: 
Table 1. Demographic Characteristics of Participants

\begin{tabular}{|c|c|c|c|c|c|}
\hline Participant No & Gender & $\begin{array}{l}\text { Education Level } \\
\text { (Last obtained degree) }\end{array}$ & $\begin{array}{l}\text { Grant } \\
\text { application } \\
\text { year }\end{array}$ & $\begin{array}{l}\text { Education } \\
\text { Field }\end{array}$ & Techno-initiative Field \\
\hline Entrepreneur 1 & Man & $\begin{array}{l}\text { Graduate } \\
\text { (PhD. Student) }\end{array}$ & 2012 & Pharmacy & $\begin{array}{l}\text { Rational } \\
\text { Design }\end{array}$ \\
\hline Entrepreneur 2 & Man & $\begin{array}{l}\text { Undergraduate } \\
\text { (Engineering Completion) }\end{array}$ & 2013 & $\begin{array}{l}\text { Automotive } \\
\text { Instructing }\end{array}$ & Automotive-Software \\
\hline Entrepreneur 3 & Woman & $\begin{array}{l}\text { Graduate } \\
\text { (PhD. Student) }\end{array}$ & 2012 & $\begin{array}{l}\text { Biomedical } \\
\text { Engineering }\end{array}$ & $\begin{array}{l}\text { Development of a } \\
\text { Laboratory Device for } \\
\text { Cells and Tissues }\end{array}$ \\
\hline Entrepreneur 4 & Man & Undergraduate & 2009 & $\begin{array}{l}\text { Computer } \\
\text { Engineering }\end{array}$ & Security- Software \\
\hline
\end{tabular}

\subsection{Findings Regarding the Contributions of TICS to Building Entrepreneurial Ecosystem}

Findings obtained as a result of analysis of data collected from interviews carried out within the study are summarized under the following themes.

4.2.1 Findings Regarding Development of Societal Welfare

\section{Employment}

Entrepreneur 2 mentions that one of the aims of the support provided by the Ministry could be to contribute to the employment.

"The Ministry of Industry was also saying that "even if two projects emerge from the program it is fine with us. Therefore, I think the state thinks that people can get experience in this way, they focus on employment." (Entrepreneur 2)

Entrepreneur 3 talks about the contributions of what she has achieved thanks to the program to the state and the society.

"Let me put it in this way, employment is achieved in the phase of the realization of the project. For example, now we are together with our third employee. First one was recruited in TUBITAK, the second one was hired by a large company. They grow up here and then they are employed in such nice places. Therefore, I can say that yes we are a part of employment, too. The grant program definitely contributes to the employment." (Entrepreneur 3)

"We have developed simple laboratory devices, we also provided the infrastructure for dosing pumps, thus if these devices are used in hospitals and scientific studies are carried out, more people can be employed. The more our laboratory devices are sold, the more we pay taxes to the state. This in fact will greatly contribute to the welfare of the society as a whole." (Entrepreneur 3)

Entrepreneur 4 clearly states that thanks to the program, their employees earn income from domestic revenue, hence this contributes significantly to employment and the welfare of the society.

"Let me tell you this, now of course we are in a small area but as our company gets larger, our employees become individuals who have high levels of welfare in the society and who earn more than the average, and hopefully it will continue to be the case as long as we sell. Why, because if you can produce technology you then sell it to high prices in abroad, of course this money comes to Turkey. Then, employers, employees get profit from this income and this of course increases the welfare of the country." (Entrepreneur 4)

\section{Eliminating External Dependence}

Entrepreneur 2 states that by reducing imported goods, it is possible to stop capital from going abroad and eliminate external dependence, then all citizens in the country can reach good life standards.

"Ideas are produced and materialized abroad then we pay and buy them. We need to prevent this and try to come up with ideas in our country because there are so many people with ideas in our country. Yes, the number of people with ideas is high but most of them cannot do anything because they don't have financial support because no one is supporting them. If we can provide that, we may cut the import of these products from abroad and if we produce them in our country, we can both reduce the money going abroad and also learn how to produce, in this way we can enhance our country's development." (Entrepreneur 2)

Entrepreneur 3 believes that in order not to be dependent on external sources, the state should provide such supports. 
"I mean if you want to be independent in the world, you must produce some things on your own. For example, it has to be done so that we won't be externally dependent on medicine. This must be a responsibility of the state." (Entrepreneur 3)

Entrepreneur 4 states that thanks to the support, domestic production occurs, this prevents added value from going abroad.

"The country must try hard to enable employment with such initiatives, to export, to create added value, and to prevent resources from going abroad. Prevention of resources from going abroad can only be possible if we produce in the country." (Entrepreneur 4)

\section{Crossing the Valley of Death}

Entrepreneur 1 mentions that the first period when the first steps are taken for the initiative is seen as valley of death by public authorities, highlights that even one single company that will survive in this period will create a value that will finance the expenses incurred by the state for all enterprises.

"Now, the state is not considering the expenses it incurs for these entrepreneurs. The state thinks about the revenue that it will bring to the country. The scale of the state is that: five out of a hundred enterprises shall survive the valley of death, and move forward; this is enough to cover the expenses that early-stage entrepreneurs cost to the state." (Entrepreneur 1)

Entrepreneur 3 states that she really encountered valley of death after she received the support, and those who want to receive the grant should consider that fact.

"It is not an easy path, you can really survive in the valley of death if you give up everything else and put up a really tough fight. This is real, I still cannot forget that graph. People can be disappointed. They can fail and suffer. If they are ready for all these, then they should consider taking the support." (Entrepreneur 3)

\subsubsection{Findings Regarding Emergence of Entrepreneurship Awareness}

Entrepreneurs involved in the research regarding the categories gathered under this theme stated that the biggest problem encountered especially during starting an enterprise was the lack of capital, they overcame this problem thanks to the state. Furthermore, they told that entrepreneurs supported by the state with a grant program feel the power of the support both in a moral and material way. However, under this theme a need arose to mention not only the concept of entrepreneur but also the concept of techno-entrepreneur.

\section{State-Supported Entrepreneur}

Entrepreneur 1 came up with a concept of state-supported entrepreneur during the interviews while talking about how state tries to create entrepreneurs with this support.

"State enables people to take risks with this support. It tries to teach people to take risks." (Entrepreneur 1)

Entrepreneur 3 mentions about the concept of state-supported entrepreneur by explaining the difference and advantages of being a state-supported entrepreneur in a Technopark.

"It is very convenient compared to outside but from this year on Technoparks will be more expensive. You can get special discount as you are supported by the state as an entrepreneur. The biggest advantage of Technopark is that you provide more jobs. They take you more seriously when you go somewhere and there is also a tax advantage." (Entrepreneur 3)

\section{Techno-Entrepreneur}

Entrepreneur 1 emphasizes that entrepreneur and techno-entrepreneur are commonly confused and even the rank of technical expert is not enough to explain techno-entrepreneur because there are some differences between them.

"We don't know the term techno-entrepreneur. Entrepreneurship has been established in the country but it is not at sufficient level. I mean people started to do something. They get bored with their fixed incomes and quit, then start their own business and try to pursue entrepreneurship by relying on KOSGEB support. Despite KOSGEB grant, they go bankrupt and are left with nothing. I see many examples like this and feel very sorry for that. That person is definitely an entrepreneur but he/she tries to compete with techno-entrepreneurs even though he/she is not one of them. His/her reading and perception of events are different than ours. He/she knows how to make money better than me. But he/she doesn't know R\&D better than me." (Entrepreneur 1)

"What we call entrepreneur is someone who sells lemonade where it is not sold before. Someone who sells lemonade where lemon doesn't grow is an entrepreneur. But when we say techno-entrepreneur, we mean someone 
who tries to find a solution to present lemonade in a more efficient, reliable way where the cost the product lemonade is high and the quality is low. In other words, while the only parameter used by an entrepreneur is market research, the parameter used by a techno-entrepreneur is adding technology besides market research." (Entrepreneur 1)

Entrepreneur 3 states that even though they have technical knowledge, techno-entrepreneurship requires way beyond having technical knowledge therefore mentorship system which depends on experience in the market is required.

"I know technical things in my field and apply them in my business. It is clear that many of us who had the grant need entrepreneurship trainings on topics such as finding the right market/customer, entering market, cash flow, etc. Therefore, I think that every enterprise which receives the grant should be guided through providing needed training and information with a special mentorship system." (Entrepreneur 3 )

Entrepreneur 2 explains the difference between entrepreneurship and techno-entrepreneurship based on his own engineering background.

"I was not aware of entrepreneurship. My only goal was to put the products I designed in the market. I was always thinking with a perspective of an engineer. Then, I became aware of such things when I first applied for technology entrepreneurship capital. I realized that starting a business and running this business were completely different things. I mean technology entrepreneurship is not just making $R \& D$ and producing technology because no matter how well we know the technical part, we still lack in marketing, accounting I mean running the business." (Entrepreneur 2)

\section{Characteristics of Entrepreneurs}

There are many characteristics of entrepreneurs defined in the literature. The characteristics that an entrepreneur must possess and the characteristics that fit best to the definition provided by entrepreneurs who received the grant were told during the interviews with below mentioned statements.

Entrepreneur 1 tells the importance of having a business idea before becoming aware of the grant support with such words.

"I had my current business idea since high school. I didn't just apply for the grant just because I saw it and formed a business idea later. When I saw the announcement of grant on the Ministry's website, I read the related regulation and told to myself that it defines me and then applied for the grant program. I was thinking about with which business idea I could become more successful and thought that the current project idea was right for me to pursue. Then I saw that it was the right choice." (Entrepreneur 1)

"Those who come up with business ideas after learning the grant program have never been successful and they cannot be. They somehow lose Imean they of course waste the state's resources." (Entrepreneur 1)

Entrepreneur 2 states that entrepreneurs should take risks and know how to fight in uncertain conditions and provides his definition of entrepreneur.

"I think an entrepreneur is someone who have been dropped into uncertainty. Because it means entering into an environment where nothing is certain and endeavouring to do something even under such circumstances with the courage of ignorance as we say." (Entrepreneur 2)

"An entrepreneur will provide benefit eventually! I think those who show a great effort to produce something that can be possibly commercialized and who are beneficial to the society are entrepreneurs. They are those who carry all the risks." (Entrepreneur 2)

Entrepreneur 3 states how an entrepreneur endures a psychological cost while striving to survive with a great effort and time.

"I am from Izmir and I haven't touched or seen the sea for the past three years. I mean I never go on vacation. I don't have weekend holidays. We work for about three hundred hours on average in a month. I pay a great cost in terms of time during pre-production periods. I don't live I work! We are always trying to survive, we are in constant fight for survival." (Entrepreneur 3)

Entrepreneur 4 explains his survival fight and the sacrifices he made in a similar way to Entrepreneur 3.

"Since we applied for the grant, we have been working for 24 hours except for sleep and, we still work a lot. I don't remember taking two days off consecutively since we started this company except for when my sister passed away. It happens a lot when I work for six months without having any day off or holiday. These are normal because when you don't do in this way, when you don't sacrifice, it is not possible to survive." 


\section{(Entrepreneur4)}

Entrepreneur 4 also mentions how they paved the way for raising awareness about entrepreneurship in the society thanks to the characteristics of an entrepreneur.

"I think as I said earlier, these grant and support programs of the state create a perfect awareness. It rings a bell in the minds of people. Because this issue is more about perspective rather than resource. I mean it contributes seriously to develop an entrepreneurship culture among young people. Because people imitate successful ones. All people imitate actually, all beings do. Therefore, when people see successful examples who utilized this grant, they want to do the same thing with their own ideas. This of course causes a domino effect and creates a serious entrepreneurship culture among all young people." (Entrepreneur 4)

\subsubsection{Findings Regarding Power Formation to Create Innovation}

\section{Technology-Based Business Idea}

Entrepreneurs who benefited from Techno-Initiative Capital Support Grant Program mention that they developed new products for the country which include high technology and are not present in our country in accordance with the requirements of the program.

Entrepreneur 4 talks about the importance of producing high technology products and the added value they brought to the country.

"If you produce things that are superior in technology and have added value, then you can earn more by working less. If you earn more the country gets happier, the rates of murders decreases, unrest in the country declines, even maybe a country won't enter into a war. The country won't have to deal with other troublesome issues. I mean if a country is stronger economically, it means that people inside the country and around the country live in happiness and welfare. This as we said can be made possible by doing qualified, innovative things which have high R\&D quality." (Entrepreneur 4)

"You know there is something called middle income trap. What is this middle income trap? In developing countries, countries get stuck at some point since there is no technology-based works as well as added value, because you need to do something different to handle that trap or not to fall into the trap. That something different is actually technology-based initiatives. "(Entrepreneur 4)

Entrepreneur 4 mentions about exports of technology products thanks to the support even though it happens in the long run.

"These are long-term investments. You cannot see the effects in the short-term but 15 years later the country's rate of technology products export will increase thanks to the Ministry's Techno-Initiative Capital Support Program." (Entrepreneur 4)

Entrepreneur 3 states that they began their journey for producing high technology products and this is of significant importance for the country.

"Actually as being very idealistic, we wanted to produce high technology products in our country and we still want to do so. In general, there is a handicap to computation and especially researchers in physical sciences encounter this situation a lot. An idea comes to your mind, you really want to do this, and you want to move forward by having the necessary device produced, but unfortunately you don't have such a chance your ideas die before they are born. However, in the USA, Germany, people can have the device they can easily have it produced, so that they can easily continue with their business ideas. We wanted to provide such an access to technology in Turkey. I mean we wanted to produce laboratory devices which would provide infrastructure for scientific studies and pave the way for such studies. We are still working on it. Especially in a developing country such as Turkey, if you want to create added value, you have to produce high technology in the country." (Entrepreneur 3)

Entrepreneur 1 mentions that public authority provides grant program in the country in order to prevent techno-entrepreneurs who are potential candidates for creating innovation from leaving the country as well as to enable them realize their business ideas with ease. He states that in this way, with the increase in level of technology production and added value in the country, the country's risk of falling into the trap of middle income will be eliminated.

"The only way to avoid falling into the trap of middle income is to have technology-based production." (Entrepreneur 1) 


\section{New Product for the Country}

Business ideas of all the entrepreneurs that were interviewed consisted of innovative products which were not developed in our country before.

Entrepreneur 1 mentions that his business idea was not realized before and he even created his own opponent.

"There was no one in Turkey who realized this idea before. I have created my own opponent after myself." (Entrepreneur 1)

...There is actually no one abroad who does it in the same way as Iplanned." (Entrepreneur 1)

Entrepreneur 2 states that nobody has ever realized his business idea in the country but there are some examples abroad however these examples have some partial differences from his business idea.

"There is no example of it in Turkey. But there is in abroad. A company in China has done it, they sell it online. Actually their features are a little similar but there are some structural differences. " (Entrepreneur 2)

Entrepreneur 3 tells that there is not this kind of company in Turkey, they are one of the significant well-known companies in the world.

"There isn't this kind of company in Turkey. I don't think it will happen. There are five companies in the world and we are the sixth one which produces this device." (Entrepreneur 3)

Entrepreneur 4 stresses that there is not such an idea in the country, even in abroad similar examples have been provoked by what they have done.

"Of course there isn't any in Turkey. They are trying to do it in abroad but they are failing. Because as I said there is a tiny detail in it therefore no one was actually working hard I mean they were trying but then they were giving up but we have noticed something, we have discovered that we could manage to do it there. I mean we found the way, we carried out $R \& D$ and then we tested it and saw. Then, when everybody sees that we are doing it, they thought that they could do it, too therefore they started to spend money on R\&D." (Entrepreneur 4)

\section{R\&D Infrastructure Development}

Entrepreneurs talk about the contributions of benefiting from this grant to R\&D infrastructure of the country.

Entrepreneur 1 states that the Ministry is trying to encourage us to carry out R\&D.

"With this grant, the Ministry enables people to take risks, the Ministry is trying to teach people how to take risks. They are encouraging companies to carry out $R \& D$. The state tries to promote companies not to be just a medium-level market company. The state tries to create new Apple's." (Entrepreneur 1)

Entrepreneur 3 states that the country needs $R \& D$ and the grant program has a significant contribution in this sense.

“The Ministry is trying to expand Turkey's R\&D area with this support however there is not any $R \& D$. Believe me, I know it very well that there is not any $R \& D$ in my field I am experiencing it thoroughly." (Entrepreneur 3)

Entrepreneur 2 states that their chances of carrying out R\&D in the country will increase thanks to the supports.

"When we look at the situation of automotive sector in our country, we can say that it is totally based on assembling. If we had our own cars/brands, if we had our own automobile companies, then maybe it will be easier to develop the technology. However, development of $R \& D$ infrastructure in our country gains momentum thanks to these supports." (Entrepreneur 2)

Entrepreneur 4 mentions about the positive effect of R\&D which he defines as "finding solutions to a problem which doesn't have a solution."

"A country's power is dependent on the economic power it has. In other words, the power of a country is made possible as long as it has innovative works with high added value, high $R \& D$ quality and high know-how. That's how we started with the support from the Ministry and our exports have already exceeded the Ministry's support. Even a well-established company in Germany said that they cannot apply a very original idea that we are working on and added that it is even impossible for us to manage to do it. But look what happened, we are exporting to many countries including Germany. We are taking back the money we pay to Germany for importing cars by selling the technologies we produce to Germany by carrying out their $R \& D$." (Entrepreneur 4)

The figure below shows the themes of the study obtained as a result of the data analysis. 


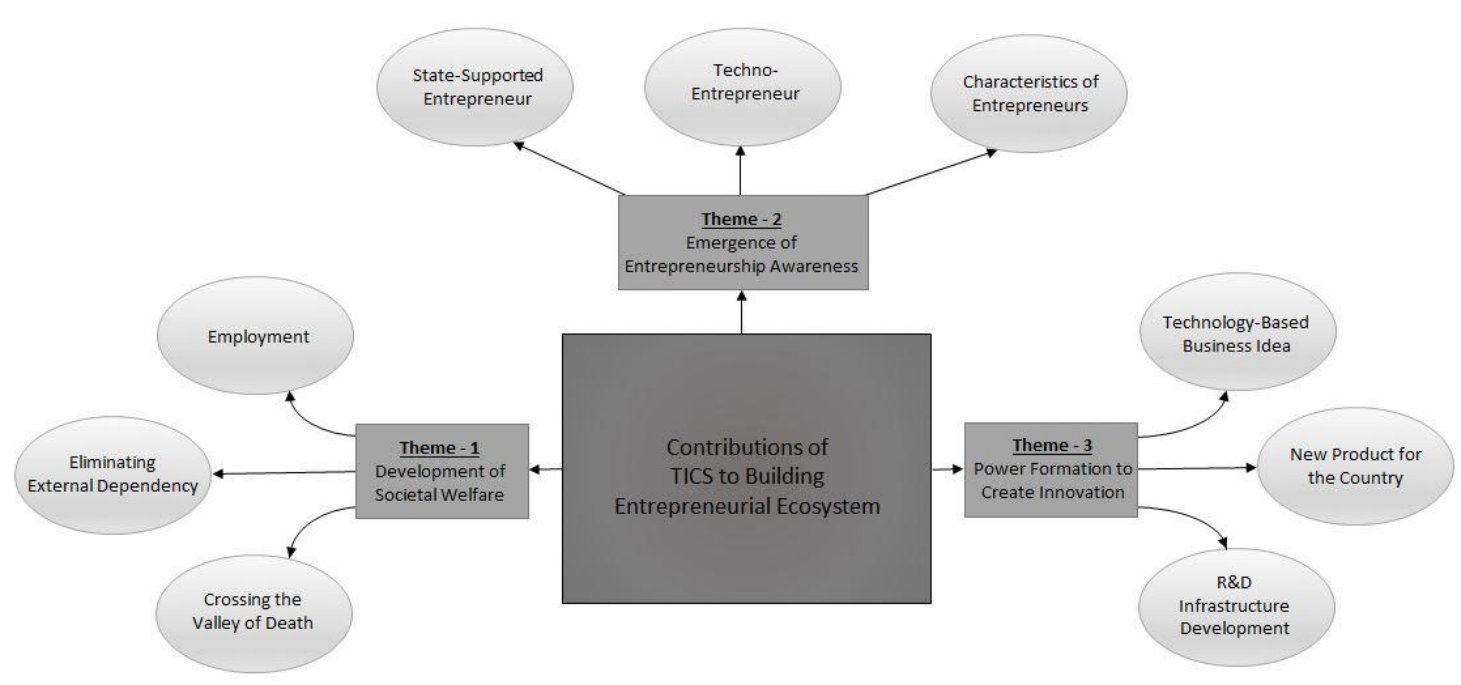

Figure 2. Contributions of TICS to Building Entrepreneurial Ecosystem in Turkey

\section{Discussion and Recommendations}

Throughout history, mankind has encountered many problems and had to find solutions for them in order to survive. In the last century, humanity is fighting against issues such as diseases resulting in deaths, addictions such as alcohol, drugs, etc., corruption, terrorism, wars, drought, poverty, climate change and global warming. While solving these problems, particularly public sector, civil society organizations, private sector play important role and cooperation is strongly needed for raising awareness in the societies. Therefore, it is possible to mention a variety of methods that societies and people develop and apply in order to provide solutions for the problems. In this context, understanding and using social marketing which is a powerful tool can be helpful in eliminating the problem. Social marketing is used a tool which will enable to develop constructive programs and applications in order to realize desired behaviour change in solving the problems which will be useful for the society.

In this study, it was aimed to tackle the social marketing within entrepreneurship scope as a different approach rather that presenting it as a resource of solution to abovementioned problems which was investigated by other studies frequently. TICS grant program which was implemented by the Ministry of Science, Industry and Technology as a public authority based on "Law on Supporting Research and Development Activities" numbered 5746 in order to build entrepreneurial ecosystem in Turkey, was investigated within the framework of the concept of social marketing. TICS program has situated itself as a state support in the process of entrepreneurship so that entrepreneurship can be promoted, companies which have high technology and added value as well as products commercialized by these companies can have a place in national and international markets in this way inno vative ideas do not remain as just ideas because of the lack of capital. This program has played an important role in building inno vation and entrepreneurship climate in Turkey as long as it remained in effect as a kind of seed funding (2009-2015).

The primary aim of social marketing is to create a change in behaviour, within this perspective preventing young individuals who have technology based and innovation business ideas from giving up their ideas of becoming entrepreneurs and enabling them to become entrepreneurs and to sustain their initiatives eventually create a behaviour change. Another important factor in behaviour change is that individuals voluntarily demand this. All young individuals who apply for the grant program act voluntarily at individual level. Besides, another important factor in social marketing is that behaviour change serves for the desired purpose. In this regard, the fact that young individuals want to become entrepreneurs and keep their enterprises contributes to building and sustaining entrepreneurial ecosystem in the country which was targeted by the grant program. The final point that the state namely the public authority wants to reach with the grant program is the capacity building in the field of innovation and entrepreneurship in Turkey. Grants given by the Ministry ensure that innovative ideas stay within the country and both those who develop the ideas and the ideas themselves do not leave the country. The facts that tendency towards innovation is increasing and ideas are realized and turned into products make it possible that Turkey moves away from externally dependent country category in terms economy and positions itself within the class of gradually industrialized countries. 
All of the techno-entrepreneurs who participated in the study do agree that a change has occurred in their behaviours because of public grants given by the Ministry as financial support. They state that public authority has tried to change their behaviour by providing them grant and they have been successful in it. These young individuals who gave up going abroad for $\mathrm{PhD}$ even though he got accepted because of the grant, who resigned from one of the leading plane producing companies in the world, who gave up starting to work in R\&D department of a firm which is among the top three companies in pharmaceutical sector in the world, mentioned that TICS program initiated by the public authority changed their behaviours. This behaviour change was planned by the public authority as a process first starting with young individuals' presentations of their technology-based business ideas as business plans, then continuing with young individuals' starting up their own companies and finally ending with preparation of prototypes of their business ideas. Here, the state paves the way for building entrepreneurial ecosystem and innovation culture with the TICS program for the benefit of the society. As a result of the intensive and detailed interviews with the techno-entrepreneurs who participated in the study, it is believed that TICS which can be considered as a social marketing application contributes to building entrepreneurial ecosystem and these contributions are gathered around three themes.

Techno-entrepreneurs who participated in the study pointed out that the first contribution of the ministry's TICS program is about the development of societal welfare. They stressed that production of technology products in the enterprises that they started will have a key role in creating employment opportunities in the country. It was mentioned that in order for Turkey to compete in the international arena, technology products must be produced in the country by preventing import of technology products in this way external dependency can be eliminated; and volume of production and export will raise the living standards of all citizens. Young entrepreneurs who received grant in TICS program stated that TICS is a kind of seed funding for them to crossing the valley of death which is considered as the situation in which business idea is not commercialized in other words it is not turned into any goods and/or services. They even underlined that it will be possible to transform innovative and creative business ideas into commercialized goods and services thanks to seed funding obtained as the grant.

Young entrepreneurs who received grant from TICS stated that another contribution of the program is that it raised an awareness of entrepreneurship on both themselves and the target audience. While mentioning about the advantages of being state-supported entrepreneurs, they stated that they carried out their woks faster and with less cost thanks to this. They highlighted the concept of techno-entrepreneur especially and frequently, and stated that they are not just entrepreneurs but also techno-entrepreneurs. In other words, they confirmed that techno-entrepreneurship is the integration of both technical expertise; knowing doing R\&D and also entrepreneurship, knowing making money and understanding market conditions. It was concluded that entrepreneurs need to endure serious psychological cost from the phase of idea till the commercialized product phase.

Techno-entrepreneurs who participated in the study stated that the third contribution of TICS is that it contributes to forming power to create innovation. In order for Turkey to compete in international arena, it is required to increase added value of the production and to raise technology level. Findings of the study also reveal that in order to avoid middle income trap especially developing countries like Turkey should integrate high technology into their production processes and enhance their technology capacities of the country by attaching importance to R\&D.

It goes without saying that TICS which is given to early-stage entrepreneurs as a support has undeniable contributions to building entrepreneurship and innovation climate in Turkey as explained and shown in depth with abovementioned findings. It is obvious that TICS as the first initiating program in creating entrepreneurship and innovation climate in has fulfilled an important mission.

Although the study was concluded with data gathered from limited number of participants, findings obtained as a result of qualitative interviews included quite detailed data for understanding the effect of TICS program. Since the study was carried out based on interpretative approach and this approach does not specify generalizability, the present study provides invaluable insights into exploring, understanding, explaining and interpreting how TICS program affect entrepreneurial ecosystem under which circumstance/circumstances. Therefore, it can be possible to provide more details regarding various dimension by collecting data from more participants in the future studies. Furthermore, qualitative method can be used again but with the help of focus group technique, platforms can be created with the participation of the coordinator of "1512 Techno-Initiative Capital Support Program BIGG", TUBITAK and experts from other implementing organizations which support TUBITAK.

\section{References}

Andreasen, A. R. (1994). Social marketing: Its definition and domain. Journal of Public Policy \& Marketing, 
13(1), 108-114.

Andreasen, A. R. (2002). Marketing social marketing in the social change marketplace. Journal of Public Policy \& Marketing, 21(1), 3-13.https://doi.org/10.1509/jppm.21.1.3.17602

Argan, M. T., \& Akyildiz, M. (2010). Social marketing approach as a tool for dissemination sport (From the perspective of sport for all). Pamukkale Journal of Sport Sciences, 1(3), 39-51.

Ayvaz, I., \& Torlak, O. (2016). Sosyal pazarlama ve ahlaki boyutları. Türkiye Iktisadi Girişim ve İş Ahlakı Dergisi, 9(2), 247-281. https://doi.org/10.12711/tjbe.2016.9.0009

Bali, S., \& Cinel, M. O. (2011). Bir rekabet aracı olarak kurumsal sosyal sorumluluk. ODÜ Sosyal Bilimler Enstitüsü Sosyal Bilimler Araşttrmaları Dergisi, 2(4), 45-60.

Bayin, G., \& Akbulut, Y. (2012). Sağlık sektöründe sosyal pazarlamanın kullanımı. Ankara Sağlık Bilimleri Dergisi, 53-72.https://doi.org/10.1501/Asbd_0000000005

Bayraktaroglu, G., \& Ilter, B. (2007). Sosyal pazarlama: Engeller ve öneriler. Ege Akademik Baklş Dergisi, 7(1), 117-132.

Bekar, S. (1995). Social Marketing. Society and Doctor, 10(68), 78-83.

Bozpolat, C., \& Comert, Y. (2016). Sağlık sektöründe sosyal pazarlama uygulamaları: Obezite ile mücadele üzerine bir araştırma. Nevşehir Hacı Bektaş Veli Üniversitesi Sosyal Bilimler Enstitüsü Dergisi, 6(1), 43-64.

Castano, M. S., Mendez, M. T., \& Galindo, M. A. (2016). The effect of public policies on entrepreneurial activity and economic growth. Journal of Business Research, 69(11), 5280-5285. https://doi.org/10.1016/j.jbusres.2016.04.125

Ekiyor, A., \& Cetin, A. (2017). Sağlı hizmeti sunumunda ve sosyal pazarlama kapsamında e-nabız uygulamasının bilinirliği. Uluslararası Sağllk Yönetimi ve Stratejileri Araştırmaları Dergisi, 3(1), 89-103.

Emerson, R. M., Fretz, R. I., \& Shaw, L. L. (1995/2008). Writing Etnographic Fieldnotes. (A. E. Koca, Trans.) Ankara: Birlesik Publications.

Erlandson, D. A., Harris, E. L., Skipper, B. L., \& Allen, S. D. (1993). Doing naturalistic inquiry: A quide to methods. Newbury Park: Sage Publications.

Eser, Z., \& Ozdoğan, F. B. (2006). Sosyal pazarlama: Toplumun refahı ve kaliteli yaşamı için. Ankara: Siyasal Publications.

Galindo, M. A., \& Mendez-Picazo, M. T. (2013). Innovation, entrepreneurship and economic growth. Management Decision, 51(3), 501-514. https://doi.org/10.1108/00251741311309625

Gegez, A. E. (2007). Pazarlama araştırmaları (2nd ed.). Istanbul: Beta Publications.

Ilter, B., \& Bayraktaroglu, G. (2007). Kar amacı gütmeyen sosyal içerikli pazarlama uygulamaları: Sosyal pazarlama. Erciyes Üniversitesi İktisadi ve İdari Bilimler Fakültesi Dergisi, 28, $49-64$.

Kestane, S. (2014). Differences between the concepts associated with social marketing. International Journal of Economic and Administrative Studies, 7(13), 193-208.

Kotler, P., \& Lee, R. N. (2005/2008). Kurumsal sosyal sorumluluk (S. Kacamak, Trans.). Istanbul: Mediacat Publications.

Kotler, P., \& Lee, R. N. (2009/2010). Yoksulluğa karşı sosyal pazarlama (Z. K. Chalar, Trans.). Istanbul: Kapital Publications.

Kotler, P., \& Zaltman, G. (1971). Social marketing: An approach to planned social change. Journal of Marketing, 35(3), July, 3-12. https://doi.org/10.2307/1249783

Kotler, P., Roberto, N., \& Lee, N. (2002). Social marketing: Improving the quality of life (2nd ed.). California: Sage Publications.

Kritikos, A. S. (2015). Entrepreneurship and economic growth. International Encyclopedia of the Social \& Behavioral Sciences (2nd ed.). 675-680. https://doi.org/10.1016/B978-0-08-097086-8.94004-2

Kurtoglu, S. (2007). Sosyal pazarlama kavramının analizi. Sosyal Bilimler Dergisi, 1, 125-134.

Lefebvre, R. C. (2011). An integrative model for social marketing. Journal of Social Marketing, 1(1), 54-72. https://doi.org/10.1108/20426761111104437

Lincoln, Y. S., \& Guba, E. G. (1985). Naturalistic inquiry, Beverly Hills, CA: Sage. 
Marangoz, M. (2016). Girişimcilikte güncel konular ve uygulamalar. Istanbul: Beta Publications.

Merriam, S. B. (2009/2013). Nitel araşttrma: Desen ve uygulama için bir rehber. S. Turan (Ed.). Ankara: Nobel Publications.

Mil, B. (2007). Nitel araştırma: Neden, nasıl, niçin? A. Yüksel; B. Mil, Y. Bilim (Ed.). Ankara: Detay Publications.

Miles, M. B., \& Huberman, A. M. (1994). Qualitative data analysis (2nd ed.). California: Sage Publications.

Peattie, K., \& Peattie, S. (2009). Social marketing: A pathway to consumption reduction?. Journal of Business Research, 62(2), 260-268. https://doi.org/10.1016/j.jbusres.2008.01.033

Punch, K. F. (2011). Sosyal araştırmalara giriş: Nicel ve nitel yaklaşımlar. Z. Etöz (Ed.). Ankara: Siyasal Publications.

Rad, S. T., \& Karatas, A. (2013). Yoksulluğun azaltılmasında sosyal pazarlama yaklaşımı. Üçüncü Sektör Sosyal Ekonomi Dergisi, 48(2), 17-31.

Rothschild, M. (1997). An historic perspective of social marketing. Journal of Health Communication, 2(4), 308-309. https://doi.org/10.1080/108107397127626

Saillard, K. E. (2010). Ruhsal hastalara yönelik damgalamaya ilişkin psikiyatrist görüşleri ve öneriler. Türk Psikiyatri Dergisi, 21(1), 14-24.

Saran, M., \& Bitirim, S. (2010). Terörle mücadelede sosyal pazarlama ve iletişim stratejileri. Uluslararası Güvenlikve Terörizm Dergisi, 1(2), 87-109.

Sarikaya, M., Bicerli, M. K., Ozdemir, B. K., Kara, F. Z., Ozdemir, A. A., Guler, B. K., \& Aksoz, E. O. (2010). Sosyal girişimcilik. S. Besler (Ed.). Istanbul: Beta Publications.

Stead, M., Hastings, G., \& McDermott, L. (2007). The meaning, effectiveness and future of social marketing. Obesity Reviews, 8(1), 189-193. https://doi.org/10.1111/j.1467-789X.2007.00340.x

Uslu, A. T., \& Marangoz, M. (2008). Kar amacı gütmeyen kuruluşlarda sosyal pazarlama ve çevre gönüllü kuruluşlara yönelik bir araştırma. Dokuz Eylül Üniversitesi Sosyal Bilimler Enstitüsü Dergisi, 10(1), 109-137.

Van Duyn, M. A. S., McCrae, T., Wingrove, B. K., Henderson, K. M., Boyd, J. K., Kagawa-Singer, M., Ramirez, A. G., Scarinci-Searles, I., Wolff, L.S., Penalosa, T. L., \& Maibach, E. W. (2007). Adapting evidence-based strategies to increase physical activity among African Americans, Hispanics, Hmong and native Hawaiinas: A social marketing approach. Public Health Research, Practice and Policy, 4(4), 1-11.

Wennekers, S., \& Thurik, R. (1999). Linking entrepreneurship and economic growth. Small Business Economics, 13(1), 27-56.

Yildirim, A., \& Simsek, H. (2011). Sosyal bilimlerde nitel araştırma yöntemleri (8th ed.). Ankara: Seckin Publications.

Yin, R. K. (1994). Case study research design and methods. USA: Sage Publications.

https://biltek.sanayi.gov.tr/TSD\%20Dkmanlar/Uygulama\%20Usul\%20ve\%20Esasları.pdf

http://stephendann.com/2009/07/21/societal-marketing-v-social-marketing/

http://erhanerkut.com/girisimcilik/teknogirisim-sermayesi-destegi-mi-engeli-mi/

http://www.resmigazete.gov.tr/main.aspx?home=http://www.resmigazete.gov.tr/eskiler/2008/03/20080312.htm\& main=http://www.resmigazete.gov.tr/eskiler/2008/03/20080312.htm

\section{Copyrights}

Copyright for this article is retained by the author(s), with first publication rights granted to the journal.

This is an open-access article distributed under the terms and conditions of the Creative Commons Attribution license (http://creativecommons.org/licenses/by/4.0/). 